COMPARISON BETWEEN THE EUROPEAN COURT OF JUSTICE

AND

EUROPEAN COURT OF HUMAN RIGHTS

\author{
MsC. Snezana BARDAROVA \\ University"Goce Delcev"-Stip
}

\begin{abstract}
European Union in its present form is a union of states and European citizens occurred on the right and has all the markings of a political community of sovereign states and is also a political community of their citizens, with a whole load of inalienable rights and freedoms based on the European and universal principles. It is the first historical attempt to replace the state violence with the postulates of the rule of law and respect for human rights and fundamental cultural values of democracy and freedom of the individual. Its basis is the communitarian law and human rights and freedoms. The fact that the European Union has developed as a consensual union of European states, with clearly specified and limited competencies in the area of the legal system and legal protection explains its political system as extremely complex decentralized structure.
\end{abstract}

Keywords: human rights, legal protection, EU

\title{
INTRODUCTION
}

Legal protection in the European Union - EU is accomplished through the legal system which is composed of the sources of law and mechanisms for the implementation of EU law and the harmonization of national legislations. Legal protection by definition involves application of law by the court and shall contain the following elements: institutional (ECJ EU and other judicial institutions and judicial institutions of the Member States), material-legal element (material communitarian law and EU law) and procedural justice element (judicial procedures and procedural means of protection). Although universal standards for basic human rights not expressly distinguished as a source of EU law, they are considered an integral part of the 
general principles of law. Treaty on European Union these standards are integrated into EU law by proclamation that the EU is based on the principles of liberty, democracy, respect for human rights and freedoms and the principle of rule of law, principles which are common to all Member States and that respected as general principles of fundamental rights guaranteed by the European Convention on Human Rights, signed in Rome in 1950, and the rights that result from the constitutional traditions of the Member States. Legal system, ie the EU judicial protection is inextricably linked to the concept of rights and freedoms of the EU.

\section{LEGAL INSTITUTIONS OF THE EUROPEAN UNION}

Exercise their legal protection in the EU European Court of Justice (ECJ) and the Court of First Instance (CBC), as well as national courts, institutions should ensure that the rule of law, proper implementation of the communitarian law and the protection of fundamental human rights and freedoms. In order to ensure the collective enforcement of fundamental human rights and freedoms has taken the European Convention on Human Rights, according to which the State Party is obliged to recognize the established rights and freedoms of all persons within its jurisdiction. Accordingly, the state is obliged to guarantee equal rights to all its citizens, and citizens of another state or stateless. The Convention is regulated and how the legal protection of human rights declared before the European Court of Human Rights (ECHR) as the only mechanism of control of the application of the provisions of the Convention.

\section{EUROPEAN COURT OF JUSTICE AS A COURT OF EUROPEAN COMMUNITIES (Protector of communitarian rights)}

European Court of Justice (ECJ), together with the Court of First Instance (CBC), the European Union make up the judicial system. Founded in 1952, first as the Court of Justice of the European Coal and Steel Community (ECSC), and in 1958 with the entry into force of the Treaty establishing the European Economic Community (EEC) and the European Atomic Energy Community (Euroatom), European Court of Justice becomes a common court of the three European Communities. With treaties of establishing the European Communities, between the institutions is provided European Court of Justice ${ }^{1}$. Court under the constitutional arrangements need to ensure compliance and uniform application of Community law in the interpretation and enforcement of contracts. ${ }^{2}$ European Court of Justice, is one of the most

\footnotetext{
${ }^{1}$ Art.. 7 , of ECSC; art. 4 , of EEC and art. 3, of EUROATOM

${ }^{2}$ Art. 31 of ECSC; art. 164 of EEC and art. 136 of EUROATOM
} 
important and influential institutions of the European Communities which mainly takes care of preserving the right of the European Union in its application and interpretation. His role in ensuring the normal operation of the integration processes is very important. European Court of Justice, ie the Court of Justice, in the system of institutions of the European Union is the protector of the right pillar of the integration which is developed right. In addition to the European Court of Justice is the foundation of the Court of First Instance in 1989godina that helps the European Court of Justice in its work, in order to ease the work that constantly increased.

European Court of Justice, whose role is to ensure that in the interpretation and application of the founding treaties (the acquis) will be obeying the law. In practice, the ECJ has the role of a mediator in disputes between the EU institutions and between the EU institutions and Member States. European Court of Justice provides the EU institutions do not exceed the powers given to them by the Treaties. It ensures compliance with EU Treaty at the national level, and by the Treaty of Maastricht has the right to impose fines for legal entities and Member States that violated EU law.

The Court has conducted a significant role in encouraging the integration processes. A series of his decisions since 1960 and expanded its jurisdiction and gave real essence of the EU legal system. Two crucial decisions in the 1960s developed the essential rules on which relies the EU legal system. In the case of Van Gend en Loos in 1963, the Court established the doctrine of direct effect, which empower EU citizens legally entitled to expect from their governments to comply with their European obligations. In 1964, the case of Costa v. ENEL, the Court established supremacy ie priority of EU law ie communities in terms of national rights, which means that when the domestic law of a Member State is inconsistent with a commitment to the EU, will be applied European law. EU law is different from international law in that individuals may seek protection from its breach before the domestic courts. This is done through a system of so-called. earlier decision of the Court, which allows national courts of the European Court of Justice to seek opinion on the European aspects of the cases submitted to them. This ECJ decision influenced the shaping of various national policies such as the right to advertise the performance of abortions or renunciation of retirement. Such decisions also contributed to the claim that the Court thus essentially became an independent participant in EU policymaking.

European Court of Justice, ie his legal status, organization, and procedures before the European Court of Justice are governed by the EC Treaty and the Protocol on the Statute of the 
Court of Justice. European Court of Justice has its headquarters in Luxembourg. It is composed of 27 judges, under the principle of one judge from each Member State of the European Union and 8 solicitors ie general lawyers, who give an opinion to the judges. Judges and AdvocatesGeneral shall be appointed for a period of 6 years and eligible for re-election and must be lawyers or academics in the field of law known knowledge of law and consistent reputation for performing the role of a judge in the highest judicial institution. Judges shall be appointed by common accord of the governments of the Member States. President of the Court shall be elected from among the judges for a term of three years, with the possibility of re-re-election. The selection is done by secret ballot. While the number of Advocates-General may, upon request of the court may be increased by a unanimous decision of the Council. Their obligation is to act impartially and independently and open a court session to present their cases reviewed by the Court of Justice. Is carried out every 3 years renaming of the Judges and AdvocatesGeneral, with the possibility of reappointment. With these appointments aims to provide variability and independence of the Court of Justice.

European Court of Justice sitting judge plenary sessions or advice of 3 or 5 judges. Before the Treaty of Nice, the European Court of Justice decided in plenary composition and tips. But, by the Treaty of Nice a reform by trial counsel are predicted as a rule, and the trial in plenium and in full composition of all judges as an exception. Trial despite advice from 3 to 5 judges, consideration and trial size (High) Council, composed of at least 11 judges, who are chaired by the President of the Court of Justice, in which council members are presidents of 3 or 5 judges and other judges. Court judge in a composition only at the request of a Member State or EU institution, as parties to the proceedings. While the Court of Justice shall sit in full within the plenum only in cases provided in agreements in principle as well as in cases when after hearing the Advocate General finds that the presented case is of particular importance. Councils make valid decisions only if their adoption by an odd number of judges, and the decisions of the councils of 3 or 5 judges are valid only if made by at least three judges, and the decisions of the Grand Council are valid if summoned nine judges, and decisions in full composition-if summoned at least 11 judges.

Jurisdiction of the European Court of Justice is regulated by the EC Treaty and secondary law, which the Court gives only limited jurisdiction. ECJ jurisdiction in principle, is to ensure the rule of law in the interpretation and application of the EC Treaty, and it is recognized by the accession of the EU Member States. Although in principle the jurisdiction of the ECJ is widely determined yet he has limited jurisdiction, which is limited by the principle of the 
division of competences between the EU institutions and Member States. European Court of Justice is competent to discuss two basic categories of items and objects that are in direct supervision (contract items to determine the injury, examination and annulment of legal acts of $\mathrm{EU}$ inaction of the authorities of the EU) and items after the previous questions on requests from the courts of the Member States. In cases that fall under the direct jurisdiction of the ECJ, the application is submitted directly to the court, which makes direct solution i.e judgment on issues of law and on the factual issues. As objects in the direct jurisdiction of the ECJ considered objects for determining a violation of the agreements by the Member State, or where the Commission considers that a Member State has not carried out the obligations of the contract, it will require an explanation for it and will give a deadline state to fulfill obligations. If after the expiry of the term the state does not act upon the request of the Commission, it shall have the right case to bring before the ECJ, which, if it decides that the request for breach of contract is founded decision which obliges the state to perform the obligations specified period. If the state fails to act upon the decision of the ECJ, the Commission proposes to notify the court and to obligate the state to pay a fine, a decision that the state failed to act upon the decision of the ECJ, it obliges the state to pay a fine. Direct request to the ECJ may be submitted by a Member State institute legal or natural person if the act (legal regulation) EU body is injured Agreement. So ECJ may decide to abolish, annul the contested act, in whole or in some of the provisions. Subjects related to inactivity EU bodies (Parliament, the Council or the Commission) i.e failure of their duty to apply to adopt legal acts or other measures for the implementation of the founding treaties, entails the possibility of Member States, other EU bodies as well as legal and natural persons who have a legal interest to be adopted act, may request a complaint to the ECJ in order to establish a violation by the authorities of the EU, which should carry out the obligations provided for by the Treaty. Well, the ECJ in its decision shall oblige the authority to enact the Act. The subjects in previous issues, the ECJ decides when certain items are resolved before the national courts of the Member States contain questions regarding the application of EU law and EU law contained a different solution than what is contained in national law. In cases in previous issues ECJ governs the relationship of the various solutions, so that the Court earlier questions opinions. So if before the competent national court or other authority of the Member State in question appears to interpret the provision of the initial contract, an act of an institution of the EU, the national court to cancel the procedure and submit an application to the European Court of Justice with a request to dismiss the expressed problem, i.e the previous question. ECJ plenary takes the view, i.e an opinion interpreting the disputed article of the initial contract or act of any of the EU 
institutions. After receiving the position of the ECJ in the previous question, the national court shall continue the procedure and make a decision. Attitudes (opinions) of the European Court of Justice after the previous questions are mandatory and have the legal force of the legal norm. To resolve cases after previous question, the national court turns to the ECJ on its own initiative or at the request of the persons who are parties to the proceedings.

On the judgments of the ECJ, there is a difference between the case when claims are submitted directly to the ECJ and that when complaints are brought before a national court, which appeals to the ECJ asking for before deciding i.e opinion. So if the complaint was filed before the ECJ, it will end before this Court, i.e the judgment will be the final solution to the dispute between the parties and will assign appropriate meeting them and that judgment is not subject to appeal. On the other hand, if the complaint is submitted to the national court, which will be national court judgments, guided by previous opinion of the ECJ whose decision will be forwarded to the national court which will rule in the case. Here, although the opinion of the ECJ is required i.e binding and without the possibility of appeal, though it is the only solution on an abstract legal question. European Court of Justice does not decide the case but provides guidance on the application of EU law, the national court decides about the relevant facts and the facts applicable law and the provisions of EC law as it was interpreted in the earlier decision of the ECJ, and national court independently determines the manner of satisfaction to the injured party. Apart from the limited role of the ECJ in this respect, its previous decisions of paramount importance as they relate to the relationship between EU law and national rights.

\section{EUROPEAN COURT OF HUMAN RIGHTS AS INTERNATIONAL TRIBUNAL FOR THE PROTECTION OF FUNDAMENTAL HUMAN RIGHTS AND FREEDOMS GUARANTEED BY THE EUROPEAN CONVENTION OF HUMAN RIGHTS}

On the basis of the European Convention for the Protection of Human Rights and Freedoms, which was prepared by the Council of Europe on 4 November 1950 and entered into force in 1953, whose main objective was to make the first step to a collective application of certain basic human rights and freedoms included in the Universal Declaration of Human Rights of 1948, was provided for protection of a series of human rights and freedoms and establish a mechanism to guarantee the fulfillment of the obligations of the Member States of the Convention. So in order to ensure compliance with obligations under the ECHR and its protocols, founded the European Court of Human Rights. This court established under the 
European Convention on Human Rights in 1950 in order to monitor compliance with this Convention by the Parties. European Convention on Human Rights or as it is formally called the Convention for the Protection of Human Rights and Fundamental Freedoms of the Council of Europe is one of the most important conventions adopted by the Council of Europe. All 47 member states of the Council of Europe and signatory of the Convention on Human Rights. Proceedings against signatories for violations of human rights can be raised from other Member States or by individuals.

European Court of Human Rights was established by the Council of Europe. Its headquarters is in Strasbourg and is the only mechanism to control the application of the provisions of the ECHR. The Court is composed of as many judges as there are Member States i.e signatories to the ECHR, i.e countries that have ratified the ECHR, numbering 47. Elect one judge from each signatory country, but not necessarily judge to be a national of the member in whose proposal he chooses. Expect judges to behave impartially, rather than as representatives of the country from which they come. There is no limit to the number of judges of the same nationality, and they are elected by the Council of Europe by a judge of the three judges proposed by each Member State for a period of six years, renewable. The term of half the judges last 3 years, which means that half the judges are elected every third year. Judges are independent in decision-making and do not represent any country, and the performance of the judicial function in ECHR incompatible the performance of any other function that affect his impartiality and independence. The mandate of the judges automatically expire when they reach the age of 70 . European Court of Human Rights shall perform its duties through the Council of 3, Council of 7 judges and Grand Chamber of 17 judges. First instance jurisdiction have Chambers of three or five judges, the Grand Chamber has secondary jurisdiction in respect of appeals against decisions of first instance advice. Grand Chamber considers cases concerning the interpretation of the ECHR and its protocols, or if the decision of a question can lead to a contradiction with the earlier decision of the Court and its decisions are final. The president and two vicepresidents of the Court, as well as the two presidents of the sections are selected plenary Court for a period of 3 years.

It was established as a permanent court with judges who are employed by him on the 1st of November 1998, which were replaced previous instruments for the implementation of the convention, if that were the European Commission of Human Rights (established in 1954) and the European Court of Human Rights (established in in 1950). The new organization of the court was the result of the ratification of Protocol 11, which the Convention has been modified 
and which entered into force in November 1998. Then came the election of judges by the Parliamentary Assembly of the Council of Europe. The court is divided into five "sections", and every section is composed geographically and gender balanced way. The entire Court elects a President and five presidents of sections, two of them at the same time and vicepresidents of the Court. The term of office of all judges is three years.

European Court of Human Rights is responsible for the interpretation and application of the European Convention on Human Rights and its protocols, when no such application made to the Court, but also is competent to decide in the event of a dispute the jurisdiction. According to the ECHR, complaints against Member States of the ECHR may be made by other Member States as well as natural and legal persons whose rights have been violated by the Member State of the ECHR. But the right to file claim for violation of a right guaranteed by the Convention may be used only if the country that violated the right is a member of the ECHR, i.e has ratified it. European Court of Human Rights under its authority an international court which decides on interstate cases and complaints by individual requirements. So each member State of the ECHR may apply to the ECHR for any violation of the provisions of the ECHR and its protocols by another Member State. Also all individuals who consider themselves to be victims of a violation of a right guaranteed by the ECHR and Protocols, by any State Party to the ECHR have the right to submit an individual request (appeal) to the ECJ in Strasbourg.

Proceedings before the European Court of Human Rights carried out the principles of contradiction and public. Each individual request is awarded to any of the sections, whose chairman is appointed by the judge-rapporteur. After a preliminary review of the matter, the judge-rapporteur shall decide whether the matter will be reviewed by one of the councils. Council may decide unanimously to declare the application inadmissible or refuse if it is possible to do without further consideration. The court may consider an individual request only if all domestic remedies have been exhausted and if you get a request within six months of the final decision of the domestic court. Regarding the admissibility of the individual request of the Court not to grant a request is anonymous or request that was previously examined by the Court or which is not completely. It mean about the individual requirements of the European Court of Human Rights has subsidiary i.e additional (auxiliary) jurisdiction in relation to the jurisdiction of the national courts and their jurisdiction is triggered if a final court judgment is violation of the ECHR. Admissibility of an individual request the court decides in the Council unanimously, and the decision on the admissibility of the application must include an explanation and must be disclosed. Proceedings before the ECHR taken before the Trial 
Chamber in the presence of representative of the respondent State. Characteristically self ECHR is that it acts only on requests directed against any country that has ratified the ECHR, i. e against actions which are the responsibility of the state authorities and he cannot act upon the requests that are directed against private individuals or organizations. If the Court declares the application admissible, it may invite the parties to submit evidence, their views and to submit a claim for just compensation and to attend the public meeting which will decide their demand. In all cases before the European Court of Human Rights, the defendant is a State party to the ECHR, whose citizen the applicant i.e the plaintiff has the right to submit written comments and take part in the discussion. The debate usually is public, but can in exceptional circumstances the Court to exclude the public. The Court first attempts to achieve a friendly settlement based on respect for human rights, as defined in the ECHR UE protocols. If the Court would reach a friendly settlement that deletes the object from its list and makes a decision that contains a brief description of the facts and the solution reached. Councils ECJ decide by majority vote. All judges participating in the decision-making, have the right to submit an opinion to the judgment, in which he will highlight whether they agree with it or not, or to give a short explanation about their disagreement with the verdict. Against the judgment of the council may be appealed to the Grand Chamber within three months from the day when the verdict was announced. So the Grand Chamber first decide on its admissibility and accepts if there is a significant issue regarding the application of the Convention or any of its protocols, or if it is a question of a general nature. The composition of the Grand Chamber President of the Court, the presidents of the councils and one judge elected after the rotation system of the judges who participated in making the initial decision by the council. ECHR judgments become final on the expiry of three months or earlier if the parties declare that they will not require examination of their case by the Grand Chamber or if they complain of the first instance decision of the Grand Chamber and he reject the appeal. If the Grand Chamber accepted the appeal he decides by majority vote and its judgments are final and binding on the states to which they refer, and their execution control the Council of Ministers, which verifies whether the Member State which is found to have violated ECHR shall take all necessary measures to fulfill its obligations arising from the judgment. At the request of the Council of Ministers, the ECHR may render its advisory opinion on the legal issues relating to the application of the ECHR and its Protocols. Requests for advisory opinions are considered by the Grand Chamber, whose opinions are adopted by a majority of votes, and they must be explained. If the advisory opinion is not unanimous opinion of the judges, any judge shall be entitled to deliver a separate opinion. 
European Court of Human Rights, interpreting and applying the provisions of the ECHR, it applies not only right but also creates the right because its decisions made by invoking the provisions of the ECHR, meaningful judicial precedents that bind and national courts

\section{CONCLUSION}

Analyzing the European Court of Justice and the European Court of Human Rights finds little misleading in terms of their similarities and links with the European Union. But researching this topic I came to the conclusion that they are two different judicial institutions, which provide different regulations in different jurisdictions, different legal status, but with a similar organizational structure with a common subject of protection, and that is the protection of basic human rights and freedoms declared and guaranteed by the European Convention on Human Rights.

European Court of Justice has the status of supreme legal protection of the right of the European Union in its application and interpretation of EU Member States, which is part of the national legal systems, and provides the Treaty establishing the European Community, and he is the protector communitarian law. European Court of Justice has its headquarters in Luxembourg and is a mediator in resolving disputes between the institutions of the European Union regarding the application and interpretation of EU law, as well as disputes between an institution of the EU and from the EU Member States. So, only the European Court of Justice decides on the application of EU law as the EU institutions and the EU Member States that by the accession to the EU are obliged to integrate EU law in national legal systems and provide its equitable application. While, in the event of a dispute concerning the application of EU law by the Member States decided by the European Court of Justice. From the above results, that the legal position of the European Court of Justice is determined by his status and authority as an international court, but as a judicial institution to apply the communitarian law which is part of the national legal systems, as a consequence of the principles of supremacy (priority) and direct application of EU law and from there to the final decisions of the European Court of Justice before the national courts. European Court of Justice has position as communitarian, common court of the Member States, as part of their legal systems, and its general competence consists in ensuring the rule of law in the interpretation and application of the Treaty on European Union. 
In contrast to the European Court of Justice, the European Court of Human Rights has the status of an international court. European Court of Human Rights was established by the Member States of the Council of Europe, in order to ensure the collective enforcement of fundamental human rights and freedoms brought the European Convention on Human Rights and with the same principle, declared the establishment of the European Court of Human Rights, as the highest and only judicial institution for the protection of basic human rights and freedoms guaranteed by the European Convention on Human Rights. European Court of Human Rights is actually a supranational court, established by the European Convention on Human Rights, which is a legal leverage of last resort for individuals who feel that their human rights have been violated by a Party to the Convention. European Court of Human Rights is located in Strasbourg, and appears as a protector of the ECHR which decides as auxiliary Court in relation to the national courts. European Court of Human Rights is only competent to decide on the application and interpretation of the European Convention on Human Rights, in cases where any of the guaranteed rights is infringed by a Member State of the EU Council, which has ratified the Convention. In fact the Member State with the ratification of the European Convention on Human Rights is committed to integrate the rights guaranteed in the national legal system and to ensure their legal protection. European Court of Human Rights is authorized only for interstate courses or individual claims against a Member State that has ratified the Convention, or of any state authority. European Court of Human Rights is not competent to deal with claims against private persons or organizations. It follows that the European Court of Human Rights is the highest international court of human rights protection that can only complain Member States Parties to the European Convention on Human Rights and the natural and legal persons, in case you have suffered some injury declared and guaranteed by the Convention, but only if the violation is committed by a State Party to the Convention.

Despite misconceptions that exist about these two judicial institutions, but I think they realize its powers different basis and in relation to basic human rights, I think that they are the primary source and subject to the protection of the European Court of Human Rights, Unlike the European Court of Justice in its decision-making takes into account and considers the fundamental human rights and the ECHR source of EU law, but they do not have the force of legal act positively in EU law. Shared responsibility of these two judicial institutions is realized on a different basis, and on the application and interpretation of the ECHR by the two courts, there are cooperative (joint) relations so that the European Court of Justice always gives 
preference to the interpretation and jurisprudence European Court of Human Rights. Well, the European Court of Justice calls for the European Convention on Human Rights and the European Court of Human Rights as general principles of law, because it has its own jurisdiction in the area of human rights. European Court of Human Rights is the only judicial rich European institution exclusively practice in the interpretation of the application and content of basic human rights, so this function should not be allowed other judicial institutions such as the European Court of Justice, which is competent to decide another form of protection.

\section{REFERENCES:}

1. Bendevski, T; "The Law of European Union" ( Faculty of Law, University "St. Kiril and Metodij" Skopje, 2001)

2. Peterson, J; Shackleton, M. "The Institutions of the European Union"(Oxford University Press, 2006)

3. Weidenfeld, W; Wessels. W. "Europa from A to Z” (Europa Union Verlag GmbH, Bonn, 2002)

4. Christoffersen, J; Madsen, M. "The European Court of Human Rights Between Law and Politics" (Oxford University Press Inc, New York, 2011)

5. Brown, L; Kennedy, T. "The Court of Justice of the European Communities" ( Sweet \& Maxwell, 2000)

6. European Convention on Human Rights

7. Treaty on European Union

8. www. enchr.coe.int 